\title{
The effect of Employee Work Related Attitudes on Employee Job Performance: A Study of Tertiary and Vocational Education Sector in Sri Lanka
}

\author{
H.A.H Hettiararchchi ${ }^{1}$, S.M.D.Y Jayarathna ${ }^{2}$ \\ 1(Lecturer/Department of Commerce and Financial Management/Faculty of Commerce and Management \\ Studies/University of Kelaniya/Sri Lanka) \\ 2(Lecturer/Department of Human Resource Management/Faculty of Commerce and Management \\ Studies/University of Kelaniya/Sri Lanka)
}

\begin{abstract}
Job performance of the employees in tertiary and vocational education sector is really important since that decides survival of this sector. Also employee attitudes are related to different aspects of human life most importantly the job he/she involved in. These attitudes are rooted in the mind of them and come out from the behaviour of the employee. Thus to sustain within the competition and to achieve the competitive advantage, it is vital to focus on the attitudes and respective job performance of the employees in a significant manner. In Sri Lankan context, there is a need to investigate that how does these employee work related attitudes affect on the job performance of the employees in the tertiary and vocational education sector in Sri Lanka. Therefore the objective of this is to identify the impact of employee attitudes on job performance. The dependent variable was employee job performance and the independent variable was employee work related attitudes consist with three sub variable named; job satisfaction, organizational commitment and job involvement. The reliability of the instruments were tested against the collected data. The purpose of this study was hypotheses testing, the type was correlational study and conducted in noncontrived setting. This study was cross sectional in time and the unit of analysis in this research was individual as the data was collected from the employees working in Tertiary and Vocational Education Sector in Sri Lanka. The questionnaire was developed by the researchers was used to collect data for the study. Findings of the study reveal that $26.7 \%$ of the variance of the job performance was significantly explained by three independent variables. Consequently, it can be concluded as that there is a significant impact of employee related work attitudes on job performance of the employees of the tertiary and vocational education of government sector in Sri Lanka.
\end{abstract}

Key Words: Work Related Attitudes, Job Satisfaction, Organizational Commitment, Job Involvement, Job Performance

\section{INTRODUCTION}

Vocational education is defined as "education and training imparted to persons for the acquisition of knowledge, operative skills, technical or craft skills or of experience needed for the pursuit of an occupation or trade" (Gazette Extraordinary of the Democratic Socialist Republic of Sri Lanka, Part 1 Sec (1), 09th September 1995). Technical and vocational education is defined by UNESCO in its terminology of technical and vocational education as "a comprehensive term referring to the educational process when it involves, in addition to general education, the study of technologies and related sciences and the acquisition of practical skills and knowledge relating to occupations in various sectors of economic and social life. The broad educational goals of technical and vocational education distinguish it from 'vocational training' which is directed to developing the particular skills and related knowledge required by a specific occupation or group of occupations". Thus providing better tertiary and vocational education is crucial as it decides the future of the country. Accordingly it is critical to focus on the attitudes and the job performance of the employees, who are working in this sector; ultimately this decides the goal achievement of this sector.

Amos \& Ristow (2004) studied that effective management of job performance was critical if the goals and objectives of the organization were to be achieved. Organizations were in existence to succeed and the achievement of the strategy through individual output places the attention directly on performance. Great interest of organizational topics that related to attitude and behavior such as organizational Commitment, job satisfaction and job performance has been sparked by its potential benefits to Individuals and organizations. This is because according to Steinhaus \& Perry (1996) cited in (Samad, 2011) committed and satisfied employees are unlikely to indicate low performance and are normally highly productive who identify with organizational goals and organizational values. The popularity of work attitudes concepts stem from its linkage with several employees' work behaviors. Although previous research emphasis has actually been on the 
behavioral work outcomes of turnover and absenteeism, it has however been recognized that employee's job performance is more important than turnover (Samad, 2011).

Attitudes are evaluative statements-either favourable or unfavourable-concerning objects, people, or events. They reflect how one feels about something (Robbins, 2003). An attitude is a predisposition to make certain kinds of judgments about people, issues and events, usually in specific situations. Personal attitudes are a reflection of the broad values held by the individual. Attitudes lead to the development of personal opinions and prejudices, as well as contributing positively to an individual's exercise of judgment. Some attitudes are held firmly and are unlikely to be changed in a person's lifetime. Others are held less firmly, and are subject to change, where the individual perceives it useful to do so (Cole, 1996). An attitude is a positive or negative feeling or mental state of readiness, learned and organized through experience that exerts specific influence on a person's response to people, objects and situations (Fishbein and Ajzen, 1974).

Elton Mayo and Fritz J. Roethlisberger (1927-1932) cited in (http://www.vectorstudy.com/managementtheories/hawtorne-effect) found that in the new classic Hawthorne studies the great attention to the work attitudes were given by the businessmen and the academics. As a result, a number of managers and personal specialists jumped to the conclusion that "if we can improve job satisfaction and morale, we can improve job performance". The businessmen initiated several actions to improve employee satisfaction. The critics of the human relations argued that, even if high job satisfaction could be shown to have some relationship to employee performance, there are associated negative consequences which were being overlooked. How employee feel about their job situation and their commitment to the organization are among the most critical consequences that managers can strive to improve (Tosi et. al, 2004).

In line with Newstorm and Davis (1993), attitudes are reasonably good predictors of behaviours. They provide clues to an employee's behavioural intentions or inclinations to act in a certain way. Positive job attitudes help to predict constructive behaviours; negative job attitudes help to predict undesirable behaviours. When employees are dissatisfied with their jobs, lack job involvement, and are low in their commitment to the organization. wide variety of consequences may follow. This result is especially likely if the feelings are both strong and persistent. Dissatisfied employees may engage in psychological withdrawal (for example, day dreaming on the job), physical withdrawal (for example, unauthorized absences, early departures, extended breaks, or work slowdowns), or even over acts of aggression and retaliation for presumed wrongs.

\section{RESEARCH PROBLEM}

Behaviour of an employee at work relates to his/her job performance. Job performance of an employee is concerned with two aspects. First, employee should perform his/her job in such a manner that it leads to achievement of desirable ends. Second, he/she should use organizational resources efficiently by avoiding or minimizing the waste in performing the job activities. Attitudes have significant effects on the behaviour of a person at work. Some of the areas of attitudes that a person in the world of work is concerned with are superior, subordinates, peers, supervision, pay, benefits, promotions or anything that leads to trigger positive or negative reactions. These attitudes reflect a particular person's likes and dislikes towards other people, objects, events and activities in that person's surrounding environment. Some of the strong attitudes are likely to affect person's behaviour and this makes the enthusiasm to study and know about attitudes.

Empirical researches discovered this relationship between employee job attitudes and employee job performance. Most of the studies have been done in the western context. To fill this research gap that needs research attention to help further build the theory and literature of employee work related attitudes and job performance. However no substantive empirical study has been conduct to investigate effect of work related attitudes on job performance in tertiary and vocational education sector in Sri Lanka. Hence this study specifically focuses on answering the research questions of is there an impact of the work related attitudes in terms of job satisfaction, organizational commitment and job involvement, on job performance of the employees of tertiary and vocational education sector in Sri Lanka?

\section{RESEARCH OBJECTIVES}

The general objective of this study was to identify the impact of the work related attitudes on the job performance of the employees of tertiary and vocational education of government sector in Sri Lanka. The study attempted to achieve the following specific objectives.

1. To identify the relationship between job satisfaction and job performance employees of tertiary and vocational education sector in Sri Lanka.

2. To identify the relationship between organizational commitment and job performance employees of tertiary and vocational education sector in Sri Lanka.

3. To identify the relationship between job involvement and job performance employees of tertiary and vocational education sector in Sri Lanka. 
4. To find the impact of the job satisfaction, Organizational commitment and job involvement on job performance employees of tertiary and vocational education sector in Sri Lanka.

\section{LITERATURE REVIEW}

\subsection{Employee Attitudes}

Robbins (2003) defined attitudes as evaluative statements and they can be either favorable or unfavorable-concerning objects, people, or events. Therefore they reflect how one feels about something. The favorable statements may provide positive effects regarding the concerned object, person or event whereas unfavorable statement may provide negative effects. An attitude is a positive or negative feeling or mental state of readiness, learned and organized through experience that exerts specific influence on a person's response to people, objects and situations. This definition of attitude has certain implications for managers. First, attitudes are learned. Second, attitudes define one's predispositions toward given aspects of the world. Third, attitudes provide emotional basis of one's interpersonal relations and identification with others. And fourth, attitudes are organized and are closed to the core of personality. Some attitudes are persistent and enduring; yet, like each of the psychological variables, attitudes are subject to change (Fishbein and Ajzen, 1975).

The early family experiences help to shape the attitudes of individuals. The attitudes of young children usually correspond to those of their parents. As children reach their teen years they begin to be more strongly influenced by peers. Peer groups are able to influence attitudes because individuals want be accepted by others. Teen ages seek approval by sharing similar attitudes or by modifying attitudes to comply with those of a group (Gibson, Ivancevich and Donnelly, 1991) stated that values and attitudes develop from early childhood onward as a result of upbringing, education and experience of life. He further declared that some people's attitudes set by their late twenties/ early thirties, and others seem to be able to retain certain flexibility throughout their life.

\subsection{Job Satisfaction}

Job satisfaction is among the important attitudes that influence human behavior in the work place. Thus, organizational behavior researchers are interested in accurately measuring job satisfaction and understanding its consequences for people at work (Wood et. al, 1976). Some of the well known definitions of job satisfaction provide clear insight of it and they were helpful for this research study. Wood and Locke (1990) defined job satisfaction as the degree to which individuals feel positively or negatively about their jobs. It is an emotional response to one's tasks as well as to the physical and social conditions of the work place. As a concept, job satisfaction also indicates the degree to which expectations in someone's psychological contract is fulfilled. Job satisfaction is likely to be higher for persons who perceive an inducements-contributions balance in their relationship with the employing organization.

Job satisfaction is the amount of pleasure or contentment associated with a job. Workers will have high job satisfaction when they have positive attitudes toward such job factors such as the work itself, recognition and opportunity for advancement. According to Smith, Kendall and Hulin (1969), job satisfaction is the extent to which a person is gratified or fulfilled by his or her work. Extensive research on job satisfaction shows that personal factors such as an individual's needs and aspirations determine this attitude, along with group and organizational factors such as relationships with coworkers, supervisors, working conditions, work policies, and compensation. Job satisfaction is referred to an individual's general attitude toward his or her job. A person with a high level of job satisfaction holds positive attitudes toward the job; a person who is dissatisfied with his or her job holds negative attitudes about the job (Robins, 2003). According to Locke (1976) job satisfaction is a pleasurable or positive emotional state resulting from the appraisal of one's job or job experiences. Implicit in Locke's definition is the importance of both affect, or feeling, and cognition or thinking. When we think, we have feelings about what we think. Conversely, when we have feelings, we think about what we feel. Cognition and affect are thus inextricably linked, in our psychology and even in our biology (Saari and Judge, 2004).

\subsection{Organizational Commitment}

According to Newstrom and Davis (1997) organizational commitment is the degree to which an employee identifies with the organization and wants to continue active participation in it. They further stated that organizational commitment is a measure of willingness to remain with the firm in the future. It often reflects the employee's belief in the mission and goals of the firm, willingness to expend effort in their accomplishment, and intentions to continue working in the organization. Allen and Meyer (1990) have identified commitment in three forms. They are affective commitment, continuance commitment and normative commitment. Affective commitment is essentially concerns the person's emotional attachment to their organization. Continuance commitment is a person's perception of the costs and risks associated with leaving their current organization. Normative commitment is a morale dimension, based on a person's felt obligation and responsibility to their employing organization. 
Organizational commitment is a person's identification with and attachment to an organization. A highly committed person will probably see himself or herself as a true member of the firm, overlook minor sources of dissatisfaction, and see himself or herself remaining a member of the organization. In contrast, a less committed person is more likely to see himself or herself as an outsider (Reichheld, 1993). Greenberg and Baron (2003) defined organizational commitment as the extent to which an individual identifies and is involved with his or her organization and /or is unwilling to leave it. This definition highlights the people's willingness to involve in organizational affairs and interest to remain in the organization as the organizational commitment. Similarly (Wood, 1996) defines organizational commitment is the degree to which a person strongly identifies with and feels a part of the organization

\subsection{Job Involvement}

Job involvement is the willingness of a person to work hard and apply effort beyond normal job expectations (Wood, 1996). Job involvement is the degree to which employees immerse themselves in their jobs, invest time and energy in them, and view work as a central part of their overall lives (Newstrom and Devis, 1997). According to Singh et al., (1998) job involvement results in an individual's tendency to exceed the normal expectation associated with his or her job. An employee with little job involvement will see it as just something to do to earn a living. Thus, all of his/her motivation is extrinsic and she/he has little or no interesting on learning how to perform the job better. On the other hand, a person with a lot of job involvement will derive intrinsic satisfaction from the job itself and will want to learn more and more about how to perform the job effectively. Job involved employees are likely to believe in the work ethic, to exhibit high growth needs, and to enjoy participation in decision making. As a result, they seldom will be tardy or absent, they are willing to work long hours and they will attempt to be high performers (Newstrom and Davis, 1997).

\subsection{Job Performance}

Every employee working within the organization is expected to perform his or her job in a dependable way. He or she is responsible for successful performance of tasks and duties involved in the job according to the employment contract. Employees accept certain job assignments and agree to do them dependably. They should feel a sense of responsibility for doing them well (Opatha, 2009). Some of the well known definitions of job performance provide clear insight of it and they can be extensive used for this research study. According Moorhead and Griffin (1999) job performance is made up of all work - related behavior. Job performance is the accomplishment of those tasks that comprise a person's job (Porter and Lawler, 1968). It means execution of total set of job related tasks. The tasks that should be performed are different from one job to another. This definition by Porter and Lawler was considered as the working definition of the research study in the chapter three of this report.

Borman and Motowidlo (1993) presented a model of job performance which reflected such behaviors that were comprehensive of job performance specialty, classified as either task or relative performance. In the performance literature, a distinction is made between in role and extra-role performance (Katz and Kahn, 1978). Extra-role performance is also conceptualized as organizational citizenship behaviors (Smith, Organ, and Near, 1983). Based on this research, Borman and Motowidlo (1993) suggested that performance can be divided into two parts, task and contextual performance.

\section{- Task Performance}

Task performance involves the effectiveness which employees perform the activities that are formally part of their job and contribute to the organization's technical core and studied that appropriate performance referred to those behaviors that maintained the vast social environment in which the technical core must function. It included more unrestricted behaviors that assisted the organizations to function.

\section{- Contextual performance}

Contextual performance comprises organizational activities that are volitional, not prescribed by the job, and do not contribute directly to the technical core. Contextual performance includes activities such as helping, cooperating with others, and volunteering, which are not formally part of the job but can be important for all jobs.

\section{CONCEPTUAL FRAMEWORK}

The conceptual model of this research describes the nature of the hypotheses of this study. According to the model the independent variable is work related attitudes, under three sub variables named job satisfaction, organizational commitment and job involvement. The dependent variable is job performance. 
Figure 1 : Conceptual Framework of the Study

Independent Variables

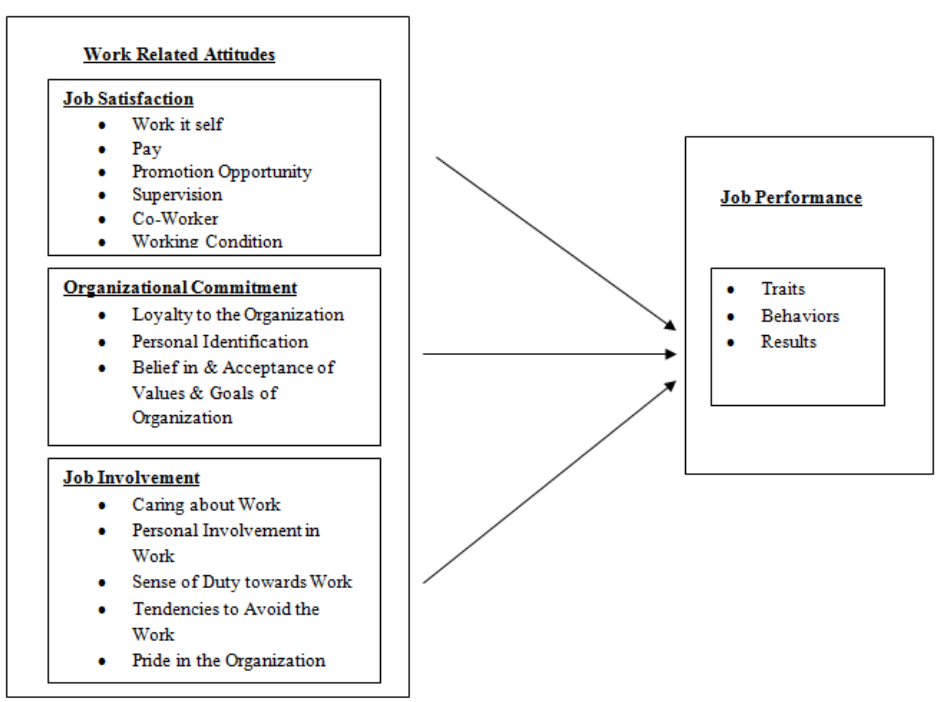

\section{HYPOTHESES}

H1: There is a positive relationship between job satisfaction and job performance of employees of tertiary and vocational education sector in Sri Lanka.

$\mathrm{H} 2$ : There is a positive relationship between organizational commitment and job performance of employees of tertiary and vocational education sector in Sri Lanka.

H3: There is a positive relationship between job involvement and job performance of employees of tertiary and vocational education sector in Sri Lanka.

H4: There is a significant impact of Job satisfaction, organizational commitment and job involvement on job performance of employees of tertiary and vocational education sector in Sri Lanka.

\section{METHODOLOGY}

Purpose of this study was hypotheses testing, since this research study was conducted to investigate the relationship between the work related attitude and job performance of the employees of tertiary and vocational education sector in Sri Lanka. According to Sekaran and Bougie (2010) studies that engage in hypotheses testing usually explain the nature of certain relationships, or establish the differences among groups or the independence of two or more factors in a situation. Also describes that there are multiple factors which influence one another and the problem (job performance) in a chain link factors, the researcher might be asked to identify the crucial factors associated with the problem, rather that establish cause and effect relationship. Thus the researcher investigated the effect of work related attitudes on job performance. Therefore the type of this study was correlational. This study was conducted in the natural environment of the organization with minimum interference by the researcher with the normal flow of work. Hence the study was conducted in a noncontrived setting.

The unit of study in this research was an individual since the data was collected from the 323 employees of the technical education and vocational training of government sector in Sri Lanka. Thus, the data for the study were collected within a particular time period and there was no subsequent extension of the research contemplated. Hence, the study was cross sectional in time horizon. Sample frame of this study was the list of registered employees at tertiary and vocational education of government sector in Sri Lanka.

This study was purely based on primary data. The survey method characterized by personally administered questionnaires was selected as the method of data collection in this study. Five point likert scale was used to weight from strongly disagree to strongly agree. In order to measure the work related attitudes, and job performance, the questionnaire was distributed to each employee in the sample. The questionnaire was originally developed in English, and then it was translated into Sinhala as the mother tongue of the employees was Sinhala.

Collected data were analyzed using the computer based statistical data analysis package, SPSS version 20.0 The data analysis includes the univariate, bivariate and multivariate analysis. Conclusions of the research were made based on these results. The statistical method used in the analysis was regression analysis and correlation analysis. 
The effect of Employee Work Related Attitudes on Employee Job Performance: A Study of Tertiary

\subsection{Reliability}

The external reliability of the instruments used to collect data was examined by Test - Retest method. This test was carried out using 10 employees of tertiary and vocational education of government sector in Sri Lanka with two weeks time interval between two administrations. As shown in the table 1, the coefficients of the Test-retest of the instruments indicate that each instrument has a high external reliability.

Table 1: Results of Test-Retest

\begin{tabular}{|l|l|l|}
\hline & Instrument & $\begin{array}{l}\text { Test-Retest } \\
\text { Coefficient }\end{array}$ \\
\hline 1 & Job Performance & 0.958 \\
\hline 2 & Job Satisfaction & 0.942 \\
\hline 3 & Organizational Commitment & 0.804 \\
\hline 4 & Job Involvement & 0.976 \\
\hline
\end{tabular}

The inter item consistency reliability was examined with Cronbach's Alpha test. The results of Cronbach's alpha test were given in the table 2, which suggests that the internal reliability of each instrument was satisfactory.

Table 2: Cronbach's Alpha Coefficients

\begin{tabular}{|l|l|l|}
\hline & Instruments & Cronbach's Alpha \\
\hline 1 & Job Performance & 0.914 \\
\hline 2 & Job Satisfaction & 0.804 \\
\hline 3 & Organizational Commitment & 0.867 \\
\hline 4 & Job Involvement & 0.896 \\
\hline
\end{tabular}

VIII. ANALYSIS

Univariate, bivariate and multivariate analyses were carried out in order to achieve the set of objectives and to test the hypotheses of the study. Pearson correlation and regression were used to test hypotheses and descriptive statistics were used to conduct univariate analysis.

8.1 Univariate Analysis

8.1.1 Frequency Distribution Analysis of Independent Variables (Job Satisfaction, Organizational Commitment, Job Involvement)

Table 3: Frequency Distribution Analysis for Independent Variables

\begin{tabular}{|l|l|l|l|}
\hline & Job Satisfaction & $\begin{array}{l}\text { Organizational } \\
\text { Commitment }\end{array}$ & Job Involvement \\
\hline $\mathrm{N}$ & 323 & 323 & 323 \\
\hline Mean & 3.6624 & 3.3249 & 3.0257 \\
\hline Std. Error of Mean & 0.02231 & 0.01858 & 0.01791 \\
\hline Median & 3.6500 & 3.2857 & 3.0000 \\
\hline Mode & 3.75 & 3.29 & 3.05 \\
\hline Std. Deviation & 0.40097 & 0.33389 & 0.32191 \\
\hline Variance & 0.161 & 0.111 & 0.104 \\
\hline Skewness & -0.453 & 0.357 & 1.159 \\
\hline Kurtosis & 1.581 & 0.263 & 4.348 \\
\hline
\end{tabular}

Table 3 depicts the frequency distribution analysis which was made individually for the variable; job satisfaction, organizational commitment and job involvement. The mean value of the distribution for job satisfaction is 3.6624. Thus it can be identified as respondents were "satisfied" with their job. The Skewness and Kurtosis of the distribution were -0.453 and 1.581 , which indicate that the data recorded for the job satisfaction are approximately normally distributed. According to the table 3, the mean value of the organizational commitment, was 3.3249. Thus, it can be identified that the respondents were "committed" to their organization. The Skewness and Kurtosis of the distribution were 0.357 and 0.263 , which indicate that the data recorded for the organizational commitment were approximately normally distributed. When considering the frequency distribution analysis for job involvement, the mean value of the distribution was 3.0257. Thus it can be identified that the respondents were "involved" in their job. The Skewness and Kurtosis of the distribution were 1.159 and 4.348 , which indicate that the data recorded for the job involvement were approximately normally distributed. 


\subsubsection{Frequency Distribution Analysis for Dependent Variable (Job Performance)}

Table 4: Frequency Distribution Analysis for Dependent Variable

\begin{tabular}{|l|l|}
\hline & Job Performance \\
\hline $\mathrm{N}$ & 323 \\
\hline Mean & 3.6469 \\
\hline Std. Error of Mean & 0.01630 \\
\hline Median & 3.6333 \\
\hline Mode & $3.43 \mathrm{a}$ \\
\hline Std. Deviation & 0.29291 \\
\hline Variance & 0.086 \\
\hline Skewness & 0.037 \\
\hline Kurtosis & 0.623 \\
\hline
\end{tabular}

As indicated by the table 4, the mean value of the distribution is 3.6469. Thus, it can be identified that job performance of respondents were "high". The skewness and Kurtosis of the distribution were 0.037 and 0.623 , which indicate that the data recorded for the job performance were approximately normally distributed.

\subsection{Bivariate Analysis}

\subsubsection{Correlation Analysis}

The bivariate analysis includes correlation analysis which was used to investigate the relationships between job performance and work related attitudes in terms of job satisfaction, organizational commitment, job involvement and job performance. Using the Pearson Product Movement Correlation with one-tailed test of significance, the correlation analysis was used to investigate the relationships exists.

Table 5 : Correlations between Independent Variables and Dependent Variable

\begin{tabular}{|ll|r|r|r|r|}
\hline & & $\begin{array}{c}\text { Job } \\
\text { Performance }\end{array}$ & Job Satisfaction & $\begin{array}{c}\text { Organizational } \\
\text { Commitment }\end{array}$ & Job Involvement \\
\hline Job & Pearson Correlation & 1 & $.416^{* *}$ & $.437^{* *}$ & $.253^{*}$ \\
Performance & Sig (1-tailed) & & .000 & .000 & .000 \\
& $\mathrm{~N}$ & 323 & 323 & 323 & 323 \\
\hline Job Satisfaction & Pearson Correlation & $.416^{* *}$ & 1 & $.448^{* *}$ & .087 \\
& Sig (1-tailed) & .000 & .000 & .060 \\
& $\mathrm{~N}$ & 323 & 323 & 323 & 323 \\
\hline Organizational & Pearson Correlation & $.437^{* *}$ & $.448^{* *}$ & 1 & $.365^{*}$ \\
Commitment & Sig (1-tailed) & .000 & .000 & & .000 \\
& $\mathrm{~N}$ & 323 & 323 & 323 & 323 \\
& & $.253^{* *}$ & .087 & $.365^{* *}$ & 1 \\
\hline Job & Pearson Correlation & .000 & .060 & .000 & 323 \\
Involvement & Sig (1-tailed) & 323 & 323 & .323 \\
& $\mathrm{~N}$ & &
\end{tabular}

**. Correlation is significant at the 0.01 level (1-tailed).

According to the table 5, pearson correlation between job satisfaction and job performance was 0.416 , which a positive relationship between job satisfaction and job performance. Further the found relationship was positive and moderately strong. The relationship was statistically significant as correlation was significant at 0.01 level (1-tailed). Thus $\mathrm{H} 1$ was accepted, as there was statistical evidence to claim that job satisfaction and job performance was positively related.

Pearson correlation between organizational commitment and job performance was 0.437 , which shows positive relationship between organizational commitment and job performance. The found relationship was positive and moderately strong. The relationship was statistically significant as correlation was significant at 0.01 level (1-tailed). Thus $\mathrm{H} 2$ is accepted, as there was statistical evidence to claim that organizational commitment and job performance was positively related.

Pearson correlation between job involvement and job performance was 0.253 , which shows a positive relationship between job involvement and job performance. The found relationship positive but weak. The relationship was statistically significant as correlation was significant at 0.01 level (1-tailed). Thus $\mathrm{H} 3$ was accepted, as there was statistical evidence to claim that job involvement and job performance was positively related. 


\subsubsection{Stepwise Multiple Regression Analysis}

Table 6: Model Summary

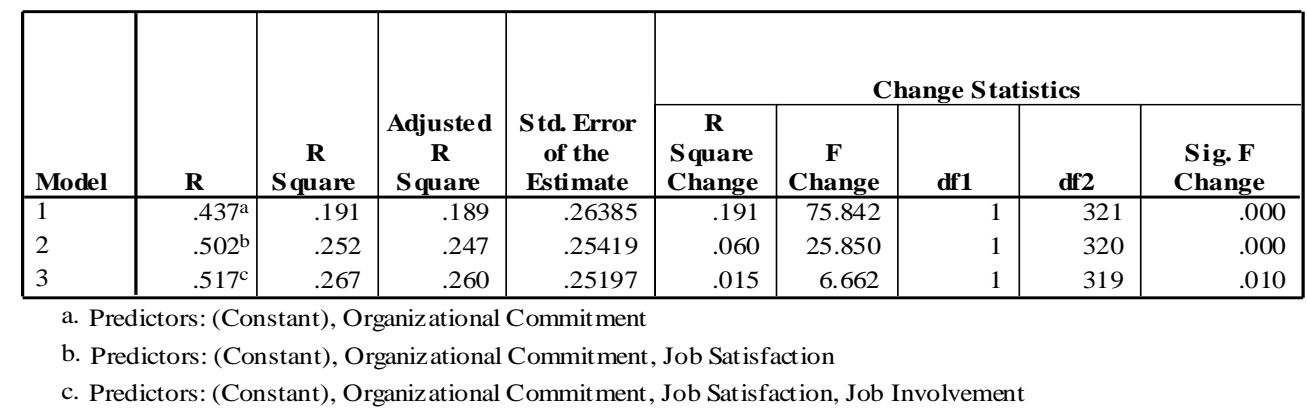

According to the stepwise multiple regression analysis, the $\mathrm{R}$ value of the model as per the table 6 was 0.517. $\mathrm{R}^{2}$ value of the stepwise regression model was 0.267 , indicating that $26.7 \%$ of variance in job performance was accounted by work related attitudes. The $\mathrm{F}$ value was 6.662 which wassignificant at $5 \%$ $(\mathrm{P}=0.010)$, which suggests that work related attitudes has significantly explains $26.7 \%$ of the variance of job performance. Thus $\mathrm{H} 4$ is accepted, as there was a $26.7 \%$ impact of work related attitudes on job performance which was significant at $0.010 .(0.010<0.05)$. Also this model depicts the correlation of the three independent variables of job satisfaction, organizational commitment and job involvement with the dependent variable job performance, after all interconnections among the three independent variables are taken into consideration. The organizational commitment provides the highest contribution to the model's R Square value, which was 0.191 and it was significant with a p-value of 0.000 . The job satisfaction and the job involvement provide the contribution to the model's R Square value by 0.060 and 0.015 respectively. The contributions provide by the job satisfaction and organizational commitment was significant with p-values of 0.000 and 0.010 respectively. In essence, the organizational commitment, job satisfaction and job involvement were contributed to the job performance by $19.1 \%, 6 \%$ and $1.5 \%$ respectively.

\section{DISCUSSION AND CONCLUSION}

According to the frequency distribution analysis was made individually for the variables of job satisfaction, organizational commitment, and job involvement. The mean value of the distribution for job satisfaction was 3.6624 and it depicted that the respondents (employees of tertiary and vocational education sector in Sri Lanka) were "satisfied" with their job. According to the frequency distribution analysis of the variable of the organizational commitment, mean value of the distribution is 3.3249 and it shows the respondents (employees of tertiary and vocational education sector in Sri Lanka) were "committed" to their organization. When considering the frequency distribution analysis for job involvement, the mean value of the distribution is 3.0257. Thus it can be identified that the respondents (employees of tertiary and vocational education sector in Sri Lanka) were "involved" in their job.

According to this stepwise multiple regression analysis, R Square value of the model is 0.267 . It indicates $26.7 \%$ of the variance of the job performance was explained by the job satisfaction, the organizational commitment and the job involvement which is significant at $5 \%(\mathrm{P}=0.010)$. Thus it shows that there was a significant impact of work related attitudes on job performance of the employees of tertiary and vocational education sector in Sri Lan a. Employees with positive attitudes toward the job tended to maintain their positive attitudes. Negative attitude employee tended to remain negative. Even those who changed job or occupations tended to maintain their prior job attitudes. Thus, attitudes tend to be consistent over time and cross related situations. Attitudes are translated into behavior via behavioral intentions. (Kreitner and Kinicki, 2004).

It was found that there was a positive relationship between job satisfaction and job performance. The Pearson correlation between these variables was 0.416 , which is significant at 0.000 level (1-tailed). Previous study suggested that job satisfaction might have an impact on several work related outcomes like job performance (Robbins, 2003), absenteeism (Lawson and Fukami, 1984) and voluntary turnover. Vroom (1964) stated that, it was typically assumed by most people associated with the human relations movement that job satisfaction was positively associated with job performance. In fact human relations might be described as an attempt to increase productivity by satisfying the needs of employees and subsequently increase the job performance.

As indicated in the empirical data, that there was a positive relationship between organizational commitment and performance was positive 0.437 which is significant at 0.000 level (1-tailed). Thus, there was statistical evidence to claim that organizational commitment and job performance are positively related. Previous studies have demonstrated that organizational commitment is positively related to employee outcomes, 
such as job satisfaction (Bateman \& Strausser, 1984), attendance (Mathieu \& Zajac, 1990), prosocial organizational behavior (O’Reilly \& Chatman, 1986), and job performance (Meyer, Allen, \& Smith, 1993), and negatively related to turnover intention (Mowday, Porter, \& Steers, 1982). The main thrust of the notion of commitment is that it can influence individual actions independently of other factors. Indeed, as a stabilizing psychological configuration giving direction to behavior, commitment can 'lead to persistence in a course of action even in the face of conflicting motives or attitudes' and may even 'lead individuals to behave in ways that, from the perspective of neutral observers, might seem contrary to their own self-interest' (Meyer \& Herscovitch, 2001).

Also it was found that there was a positive relationship between job involvement and job performance, as the pearson correlation was 0.253 which was significant at 0.000 level (1-tailed). The found relationship was positive and weak. Thus, there was statistical evidence to claim that job involvement and job performance were positively related.Employees with a high level of job involvement strongly identified with and really care about the kind of work they do. High levels of job involvement have found to be related to fewer absences and lower labour turn over (Robbins, 2005).

\section{SignifiCANCE}

This research would be valuable for individuals working in organizations in the technical education and vocational training sector, and country as a whole. At the individual level, this research study would be ready to lend a hand in improving individual performance and thereby to gain higher rewards and benefits to individuals. Also the research provides guidance to change the attitudes towards work in a better manner, in such a way it gives more self satisfaction to the individuals. This is very important, because only the self satisfaction of the work last long for years and provides the energy and enthusiasm for an individual.

Organizations in the technical education and vocational training sector would be benefited from this study. They can use this research to enhance the performance of the employees of tertiary and vocational education of government sector in Sri Lanka and thereby to increase the performance of the entire organization through the new insight that provides in the research to shape the employee job attitudes towards more positive ones. As a result, this research study would provide new insight and new knowledge regarding employee job attitudes and job performance. This is very important in this knowledge based society, because knowledge gives power. Further, by considering the above facts, it can identify that this research would accommodate organizations in vocational education sector to build a workforce with right set of work attitudes. This is a must for prosperity in today's context due to high competitiveness coming from the environment.

Tertiary and vocational education sector generates human capital for a country and for its economy by producing skilled and knowledgeable workforce. This sector is especially important to Sri Lanka, because Sri Lankan government spends large sums of money every year for this sector as a future investment in human capital of Sri Lanka. Thus, this sector is very important for Sri Lankan economy and the quality of the workforce produced by this sector depends on quality of the services it receives. Since the job performance is a function of job attitudes, it is hoped that this research will provide important information which will be of great value to Sri Lanka and Sri Lankan economy. This is because this research provides fresh insights as to enhance the employee performance through building right set of job attitudes.

\section{LIMITATIONS}

This study was to identify the impact of work related attitudes on job performance of the employees of tertiary and vocational education of government sector in Sri Lanka. Only three variables were identified under the work related attitudes. But there are many other attitudes which are related with the work/job and affecting to the job performance of the employees. So selecting only three attitudes is a limitation.

Another limitation of the study was that, this study was a cross sectional study, the data was collected only one time, hence the data was collected in one and half months. Also Data was collected only using a standard questionnaire. But the data can be collected through observation, interviews, since this study has investigated attitudes which are related to the work of the employees.

\section{REFERENCES}

[1] Allen, N. J., \& Meyer, J. P. (1990). The measurement and antecedents of affective, continuance, and normative commitment to the organization. Journal of Occupational Psychology, 63, 1-18

[2] Amos, T.L., Ristow, A. and Ristow, L. 2004. Human Resource Management (2nd Edition). Lansdowne: Juta and Co Ltd.

[3] Bateman, T. \& Strasser, S. (1984). "A longitudinal analysis of the antecedents of organizational commitment". Academy of Management Journal, 21, 95-112.

[4] Borman, W. C., and Motowidlo, S. J. (1993), Expanding the Criterion Domain to Include Elements of Contextual Performance. In N. Schmitt \& W. C. Borman (Eds.), Personnel Selection in Organizations (Pp. 71-98). San Francisco: Jossey-Bass.

[5] Cole, M. (1996). Cultural psychology: A once and future discipline. Cambridge, MA: The Belknap Press 
[6] Fishbein, M., \& Ajzen, I. (1974). Attitudes towards objects as predictors of single and multiple behavioral criteria. Psychological Review, 81, 59-74.

[7] Gazette Extraordinary of the Democratic Socialist Republic of Sri Lanka, Part 1 Sec (1), 09th September 1995).

[8] Ghorpade, J., Lackritz, J. and G. Singh (2001). Work Values and Preferences for Involvement of Employees in the Management of Organizations. Paper presented at the Annual Conference of the Association of Employment Practices and Principles, San Francisco, October 18-20, 2001.

[9] Gibson, J.L., Ivancevich, J.M., and Donnelly, J.H. (1991). Organizational Behavior, Boston: IRWIN, Inc

[10] Greenberg, J., \& Baron, A. B. (2003). Behavior in organizations (8 ed.). Upper Saddle River, NJ: Prentice Hall

[11] Katz, D., \& Kahn, R. (1978). The social psychology of organizations (2nd ed.). NY: Wiley.

[12] Kreitner, R. \& Kinicki, A. 2004. Organisational behaviour (6th ed). New York, NY: McGraw-Hill

[13] Lawson, E. W. and C. V. Fukami. (1984), Relationship between Workers Behaviour And Commitment to the Organisation and Union, Best Paper Presented at The 44th Annual Meeting of the Academy of Management, New Orleans, Lousiana

[14] Locke, E. A. (1976). The nature and causes of job satisfaction. In M. D. Dunnette (Ed.),Handbook of industrial and organizational psychology (pp. 1297 - 1349). Chicago: Rand McNally

[15] Mathieu, J. E., \& Zajac, D. (1990). A review and meta-analysis of the antecedents, correlates, and consequences of organizational commitment. Psychological Bulletin, 108, 171-194

[16] Meyer, J. P., \& Herscovitch, L. (2001). Commitment in the workplace: Toward a general model.Human Resource Management Review, 11, 299-326

[17] Moorhead, G., and Griffin, R.W. (1999), Organizational Behaviour: Managing People and Organization, 3rd Ed, Mumbai: Jaico Publishing House.

[18] Mowday, R., Porter, L., \& Steers, R. (1982). Employee-organization linkages: The psychology of commitment, absenteeism, and turnover. New York: Academic Press

[19] Newstrom, J.W. \& Davis, K. (1993). Organizational behavior: Human behavior at work. New York: McGraw Hill.

[20] O'Reilly, C. A., \& Chatman, J. (1986). Organizational commitment and psychological attachment: The effects of compliance, identification, and internalization on prosocial behavior. Journal of Applied Psychology, 71, 492-499.

[21] Opatha, H.H.D.N.P. (2009), Human Resource Management.

[22] Porter, L.W. and Lawler, E.E. (1968), Managerial Attitudes and Performance, Irwin- Dorsey, Homewood, IL

[23] Reichheld, F.F. (1993). Loyalty-based management. Harvard Business Review, 71(2), 64-73

[24] Robbins, S. P. (2003). Organisational behaviour: global and Southern African perspectives. Cape Town, Pearson Education South Africa.

[25] Robbins, S. P. (2005). Essentials of Organisational Behaviour. New Jersey: Pearson.

[26] Saari, L.M., \& Judge, T. A. (2004). Employee Attitudes and Job Satisfaction. Human Resource Management, 43 (4): $395-407$.

[27] Samad, S. (2011). The Effects of Job Satisfaction on Organizational Commitment and Job Performance Relationship: A Case of Managers in Malaysia's Manufacturing Companies. In: European Journal of Social Sciences, 18(4), 602-611 [2012-03-25]

[28] Sekaran, U., \& Bougie, R. (2010, Fifth Edition). Research Methods for Business, A Skill Building Approach.

[29] Singh, B., Gupta, P.K., \& Venugopal, S. (2008). Organizational commitment: Revisited, Journal of the Indian Academy of Applied Psychology, 34(1): 57-68

[30] Smith, C.A., Organ, D.W., \& Near, J.P. (1983). Organizational citizenship behavior: Its nature and antecedents. Journal of Applied Psychology, 68, 653-663.

[31] Smith, P.C., L.M. Kendall, and C.L. Hulin (1969). The Measurement of Satisfaction in Work and Retirement. Chicago: Rand McNally.

[32] Tosi, H.L., Misangyi, V.F. and Fanelli, A. (2004) CEO charisma, compensation, and firm performance. Leadership Quarterly. Vol 15, No 3, June. pp405-420

[33] Vroom, V. H. (1964), Work and Motivation, New York: Wiley.

[34] Wood, R., \& Locke, E. (1990). Goal setting and strategy effects on complex tasks. In B. Staw \& L. Cummings (Eds.), Research in organizational behavior (Vol. 12, pp. 73-109

[35] Wood, Olin R. (1976). Measuring Job Satisfaction of the Community College Staff

[36] Wood, S. (1996). High commitment management and payment systems. Journal of Management Studies, $33: 53-57$.

[37] http://www.unevoc.unesco.org/tvetipedia.0.html?\&tx_drwiki_pi1\%5Bkeyword\%5D=TVET

[38] http://www.vectorstudy.com/management-theories/hawtorne-effect. 